\title{
Phenotypic and genetic diversity of watermelon (Citrullus lanatus) in East Java, Indonesia
}

\author{
ACHMAD AMZERI ${ }^{1, \boldsymbol{v}}$, KASWAN BADAMI ${ }^{1}$, GITA PAWANA ${ }^{1}$, MOH. ALFIYAN SYAH ${ }^{1}$, \\ BUDI SETIADI DARYONO ${ }^{2, \bullet \varphi}$ \\ ${ }^{1}$ Agroecotechnology Program, Faculty of Agriculture, Universitas Trunojoyo Madura. Jl. Raya Telang, Bangkalan 69162, East Java, Indonesia. \\ Tel.: +62-31-3011146, Fax.: +62-31-3011506, `email: aamzeri@gmail.com \\ ${ }^{2}$ Laboratory of Genetics and Breeding, Faculty of Biology, Universitas Gadjah Mada. Jl. Teknika Selatan, Sleman 55281, Yogyakarta, Indonesia. \\ Tel.: +62-271-580839, Fax.: +62-271-6492355, ${ }^{\vee *}$ email: bs_daryono@mail.ugm.ac.id
}

Manuscript received: 12 September 2021. Revision accepted: 31 October 2021.

\begin{abstract}
Amzeri A, Badami K, Pawana G, Alfiyan Syah M, Daryono BS. 2021. Phenotypic and genetic diversity of watermelon (Citrullus lanatus) in East Java, Indonesia. Biodiversitas 22: 5223-5230. The assembly of hybrid watermelon (Citrullus lanatus Thumb.) varieties with superior characters is an effort to meet the needs of watermelon seeds in Indonesia and reduce dependence on imports of watermelon seeds. The morphological characterization of exploratory watermelon plants is needed to support the as sembly of superior varieties because morphological characterization will reveal the characteristics of each watermelon tested. In addition, the genetic and phenotypic diversity coefficients, heritability, and correlation between characters are needed to support the assembling of the desired variety. This research aimed to determine morphological diversity, genetic and phenotypic diversity coefficients, heritability, and correlation among characters of watermelon from East Java, Indonesia. The research used a randomized complete block design with ten genotypes as treatment and three replications,. The observed morphological characters were quantitative and qualitative characters. The number of characters was 60 characters. Eight quantitative characters, i.e., flowering date, harvesting date, fruit length, fruit diameter, skin thickness, fruit total soluble solids, number of seeds, and fruit weight were used to calculate the genetic and phenotypic diversity coefficient, heritability, and correlation between characters. Quantitative character data were subjected to analysis of variance, followed with a Duncan Multiple Range Test $(\mathrm{p}<0.05)$. The results showed that (i) Grouping based on morphological characters produces dendrograms with similarity coefficients ranging from 0.58 to 0.86 or there was a morphological diversity of 0.14 to 0.42 , (ii) The phenotypic diversity coefficient (PDC) was greater than the genotypic diversity coefficient (PDC) in all observed quantitative characters, (iii) The broad sense Heritability values of the tested watermelon genotypes ranged from 0.33 to 0.99, (iv) Fruit weight was significantly and positively correlated with fruit diameter, skin thickness, and number of seeds, (v) G1, G2, and G6 were the genotypes that can be used as parents to assemble superior watermelon varieties.
\end{abstract}

Keywords: Genetic variance, heritability, morphological diversity, phenotypic variance, watermelon

\section{INTRODUCTION}

Watermelon (Citrullus lanatus Thumb.) is an annual fruit plant with high economic value and is widely grown in various countries worldwide. This plant is widely cultivated in tropical and subtropical regions including Southeast Asia, Africa, the Caribbean, and the southern part of the United States (Saediman et al. 2020; Vinhas et al. 2021). In Southeast Asia, Indonesia is the second-largest watermelon producer, after Vietnam, with total production in 2017 of 499,475 tons (planted area of 32,558 ha), in 2018 of 481,727 tons (planted area of 31,699 ha), and 2019 of 523,355 tons (planted area of 34,505 ha) (FAO 2021). This amount of production can still meet the national needs, even Indonesia exported 165.01 tons of watermelon in 2018 (BPS-Statistics Indonesia 2018).

The problem with watermelon cultivation in Indonesia is the insufficient supply of watermelon seeds which caused the importation of seeds from Japan, Taiwan, and Europe (Jasmine et al. 2014). The need for watermelon seed in Indonesia is about 14.70 tons while the domestic watermelon seed production is around 12.50 tons, thus, imported seeds of 2.20 tons are required to fulfill the national demand (BPS-Statistics Indonesia 2015). The scarcity of superior watermelon seeds causes the price of watermelon seeds to be very expensive so that it is not profitable for farmers in Indonesia. The assembly of hybrid watermelon varieties with superior characters is an effort to meet the needs of watermelon seeds in Indonesia and reduce the dependence on imports of watermelon seeds from abroad.

The first step in assembling superior watermelon varieties is to explore local cultivars in the watermelon planting centers. Plant exploration aims to collect germplasm as a source of genes in the assembly of plant varieties in plant breeding programs (Samadia and Haldhar 2020). The use of local varieties in the assembly of superior varieties is often recommended to expand the genetic background of the resulting improved varieties (Casanas et al. 2017). The use of local varieties that contain genes controlling resistance to various environmental stresses can increase the superiority of superior varieties to be produced through a plant breeding program (Levi et al. 2017; Khairullah et al. 2021; Walters et al. 2021). 
Exploration of local watermelons in East JavaIndonesia has been carried out in 2019. East Java Province was selected as the place for watermelon plant exploration because it is Indonesia's largest watermelon producing province, accounting for 26.31 percent of the country's total watermelon production (BPS-Statistics Indonesia 2017). One of the watermelon planting centers in East Java is Madura Island. Madura Island has a large sub-optimal land area with low annual rainfall of $1346.89 \mathrm{~mm}$ (Suhartono et al. 2020), hence local cultivars obtained from Madura Island have the potential to be resistant to environmental stress and early maturity. These local cultivars can assemble varieties resistant to environmental stress and early maturity, which are needed for planting in areas with low rainfall (Amzeri et al. 2020). The number of local cultivars obtained in Madura Island was three genotypes. In addition, there were five local cultivars in Lamongan Regency, so that eight local cultivars were obtained from exploration in East Java Province.

The morphological characterization of exploratory watermelon plants is needed to support the assembly of superior varieties because morphological characterization will reveal the characteristics of each watermelon tested. Morphological information, for plant breeders, is not only used to see the morphological similarities between the watermelon plants tested, but also to obtain genetic information about the relationship between the watermelon plants tested (Gichimu et al. 2009). In the assembly of varieties, information on the relationship between breeding materials plays an important role in the efficient selection of parents through plant breeding programs (Choudhary et al. 2012; Kartahadimaja et al. 2021). Breeding materials with distant relatives are needed to determine the parents of the cross to assemble the desired variety (Gbotto et al. 2016). Crosses between parents of distant relatives will produce offspring with wide genetic segregation, making it easier to choose the desired variety (Pessoa et al. 2015). In addition, the genetic and phenotypic diversity coefficient, heritability, and correlation between characters are needed to support the assembling of the desired variety (Kuswantoro 2017; Wehner et al. 2017). This research aimed to determine the morphological diversity, genetic and phenotypic diversity coefficients, heritability, and correlation among characters of watermelon from East Java, Indonesia.

\section{MATERIALS AND METHODS}

\section{Plant materials}

Plant materials used were ten genotypes of watermelon consisting of eight locally explored genotypes and twohybrid varieties as checks (Legyta and Gonzales). Exploration and collection of eight local watermelons in East Java Province, Indonesia (Table 1, Figure 1) was conducted from April to August 2019. The main annual rainfall data and temperature are taken from the meteorology station at the research location. The eight genotypes were purified five times by selfing from September 2019 to December 2020 and tested for their morphological diversity from January to March 2021.

\section{Field experiment}

The research was conducted in Bangkalan Regency, Madura, Indonesia. The research location is located at latitude: $7^{\circ} 09^{\prime} 14.8^{\prime \prime} \mathrm{S}$, longitude: $112^{\circ} 44^{\prime} 01.6^{\prime \prime} \mathrm{E}$, altitude: $5 \mathrm{~m}$, average annual rainfall: $269 \mathrm{~mm}$, temperature: 28$32^{\circ} \mathrm{C}$, Grumusol soil type, $\mathrm{pH}: 7.1$. The research used a randomized complete block design with ten genotypes as treatment and three replicates, so there were 30 experimental units. Each experimental unit consisted of ten plants. Ten-day-old watermelon plants were transferred to beds with dimensions of $3.0 \mathrm{~m} \times 3.5 \mathrm{~m} \times 0.7 \mathrm{~m}$ (length $\mathrm{x}$ width $x$ height) with a spacing of $60 \mathrm{~cm} \times 250 \mathrm{~cm}$. Basal fertilization was carried out during soil preparation at the rate of $150 \mathrm{~kg} \mathrm{NPK} \mathrm{ha}{ }^{-1}$ (2:2:1), and organic manure was applied at the rate of 10 tons $\mathrm{ha}^{-1}$. NPK fertilizer was also applied at weekly intervals at the rate of $2 \mathrm{~g}$ per plant starting at 14 days after planting. After the plants had entered the generative phase, NPK fertilization was performed at the rate of $3 \mathrm{~g}$ per plant at weekly intervals. Plant pests and diseases are controlled according to plant conditions. Each plant is kept one watermelon on segment number eight.

The observed morphological characters were quantitative and qualitative characters. The number of characters measured was 60 characters. Eight quantitative characters, i.e., flowering date, harvesting date, fruit length, fruit diameter, skin thickness, fruit total soluble solids, number of seeds, and fruit weight were used to calculate the genetic and phenotypic diversity coefficient, heritability, and correlation between characters.

Table 1. Data of location and climate of watermelon exploration

\begin{tabular}{|c|c|c|c|c|c|}
\hline Genotype & Location & Latitude longitude & $\begin{array}{c}\text { Alt } \\
\text { (m asl.) }\end{array}$ & $\begin{array}{l}\text { Mean annual } \\
\text { rainfall (mm) }\end{array}$ & Temp. $\left({ }^{\circ} \mathrm{C}\right)$ \\
\hline G1 & Gellaman, Arjasa, Sumenep & $6^{\circ} 57^{\prime} 00.6^{\prime \prime S}, 115^{\circ} 19^{\prime} 35.2^{\prime \prime} \mathrm{E}$ & $30 \mathrm{~m}$ & 1395 & $21.10-35.40$ \\
\hline $\mathrm{G} 2$ & Saobi, Kangayan, Sumenep & $6^{\circ} 59^{\prime} 26.8^{\prime \prime S}, 115^{\circ} 26{ }^{\prime} 27.5^{\prime \prime} \mathrm{E}$ & $5 \mathrm{~m}$ & 761 & $21.00-35.00$ \\
\hline G3 & Tlogoretno, Brondong, Lamongan & $6^{\circ} 54^{\prime} 42.1 " \mathrm{~S}, 112^{\circ} 12^{\prime} 38.5^{\prime \prime} \mathrm{E}$ & $18 \mathrm{~m}$ & 2023 & $27.44-33.60$ \\
\hline G4 & Tlogoretno, Brondong, Lamongan & $6^{\circ} 55^{\prime} 21.9^{\prime \prime} \mathrm{S}, 112^{\circ} 12^{\prime} 28.1^{\prime \prime} \mathrm{E}$ & $12 \mathrm{~m}$ & 2023 & $27.44-33.60$ \\
\hline G5 & Bulu tengger, Sekaran, Lamongan & $7^{\circ} 04^{\prime} 17.8^{\prime \prime S}, 112^{\circ} 16^{\prime} 37.8^{\prime \prime} \mathrm{E}$ & $6 \mathrm{~m}$ & 3129 & $19.70-32.10$ \\
\hline G6 & Miru, Sekaran, Lamongan & $7^{\circ} 04^{\prime} 00.6^{\prime \prime S}, 112^{\circ} 16^{\prime} 23.5^{\prime \prime} \mathrm{E}$ & $6 \mathrm{~m}$ & 3129 & $19.70-32.10$ \\
\hline G7 & Pamaroh, Kadur, Pamekasan & 706'11.1"S, 113³0'23.9"E & $121 \mathrm{~m}$ & 1287 & $28.00-30.00$ \\
\hline G8 & Sukorame, Sukorame, Lamongan & $7^{\circ} 20^{\prime} 53.3^{\prime \prime S}, 112^{\circ} 06 ' 39.8^{\prime \prime} \mathrm{E}$ & $38 \mathrm{~m}$ & 2738 & $27.44-33.60$ \\
\hline
\end{tabular}




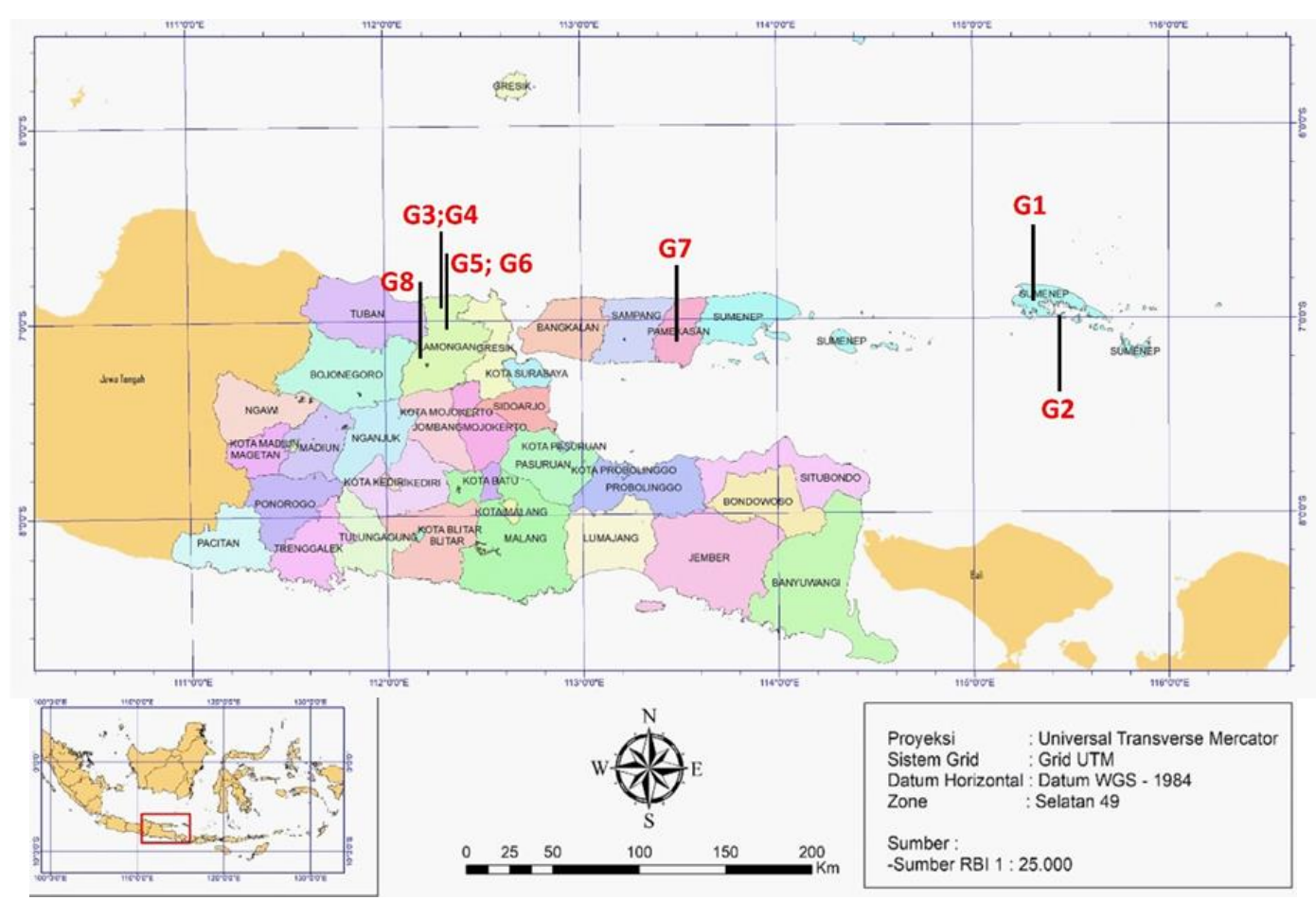

Figure 1. Location of local watermelon collection in East Java Province, Indonesia. G1-G8 indicates the location of the watermelon collection in Table 1

\section{Data analysis}

The modus method was used to analyze the qualitative data collected. Furthermore, the kinship analysis was carried out with the UPGMA (Unweighted Pair Group Method With Arithmetic Mean) method using the Numerical Taxonomy and Multivariate Analysis System (NTSYS version 2.1) software. Before being analyzed using software, the qualitative data was compiled into binary data. The characters that the watermelon genotype lacked were given the number 0 , whereas the characters that the watermelon genotype held were given the number 1.

Quantitative character data was subjected to ANOVA and DMRT post hoc test $(\mathrm{p}<0.05)$, performed using SPSS software version 22.0. Estimates of environmental, genetic, and phenotypic variances were calculated based on the expected value of the mean square of each parameter (Singh and Chaudary 1979). Based on Allard (1960), estimation of broad-sense heritability value $\left(\mathrm{h}^{2}{ }_{\mathrm{bs}}\right)$ was carried out. Pearson correlation coefficient analysis based on Walpole (1982) to determine the close relationship between the observed characters.

\section{RESULTS AND DISCUSSION}

\section{Morphological characters}

The cluster analysis results produced from the morphological similarity matrix of watermelon which is shown in Table 2 provided no grouping based on the origin or exploration outcomes, but rather on the similarity of 60 morphological traits. Genetic drift and selection in different environments can cause genetic diversity greater than the distance from the area where the plant grows, meaning that even if a watermelon genotype comes from the same place, especially on quantitative characters, if the environment where it grows is different, it will affect genetic diversity (Munisse et al. 2011; Guo et al. 2013). According to Uslan et al. (2020), genotypes originating from the same area are not always in the same group. Genotypes with a lot of morphological character similarities have a tighter association, while genotypes with a few morphological character similarities have a more distant relationship (Basyuni and Jayusman 2019).

Grouping based on morphological characters produced dendrograms with similarity coefficients ranging from 0.58 to 0.86 or there is a morphological diversity of 0.14 to 0.42 (Figure 2). The morphological diversity is shown in Figures 3, 4, and 5. The large similarity between the genotypes indicates that these genotypes have a close relationship. At a similarity of 0.58 , there are two main groups. Group 1 consisted of G1, G2, and G7, while group 2 consisted of G3, G4, G5, G6, G8, Legyta variety, and Gonzales variety. Group 1 was united by the similarity of the character of the flower bud shape, depression at fruit base, depression at the fruit apex, size of pistil scar, flesh main color, number of seeds, seed size, and ground color of seed testa, while group 2 was united by the similarity of characters in fruit shape in longitudinal section and depression at the fruit apex. Group 2 formed two subgroups, i.e., group A consisted of G3, G4, G5, G6, Legyta variety, and Gonzales variety, while G8 separated from group A to form its own group (Group B) due to differences in petiole color, basic skin color intensity, and pericarp color. 
Table 2. The similarity index value of ten watermelon genotypes (\%)

\begin{tabular}{|c|c|c|c|c|c|c|c|c|c|c|}
\hline & G1 & G2 & G3 & G4 & G5 & G6 & G7 & G8 & G9 & G10 \\
\hline G1 & 100.00 & & & & & & & & & \\
\hline G2 & 71.60 & 100.00 & & & & & & & & \\
\hline G3 & 70.00 & 68.30 & 100.00 & & & & & & & \\
\hline G4 & 55.00 & 65.00 & 65.00 & 100.00 & & & & & & \\
\hline G5 & 61.60 & 56.60 & 70.00 & 65.00 & 100.00 & & & & & \\
\hline G6 & 60.00 & 58.30 & 68.30 & 56.60 & 78.30 & 100.00 & & & & \\
\hline G7 & 71.60 & 85.00 & 68.30 & 60.00 & 53.30 & 56.60 & 100.00 & & & \\
\hline G8 & 52.00 & 55.00 & 63.00 & 53.30 & 66.60 & 66.60 & 58.30 & 100.00 & & \\
\hline G9 & 60.00 & 53.30 & 76.60 & 75.00 & 65.00 & 65.00 & 50.00 & 58.30 & 100.00 & \\
\hline G10 & 61.60 & 48.30 & 60.00 & 63.30 & 63.00 & 63.30 & 51.60 & 55.00 & 65.00 & 100.00 \\
\hline
\end{tabular}

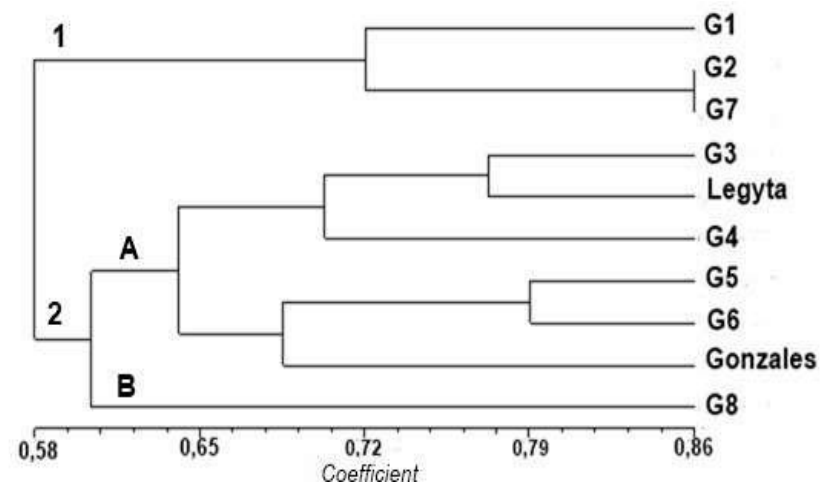

Figure 2. Dendrogram of watermelon genotypes from East Java-Indonesia based on morphological characters

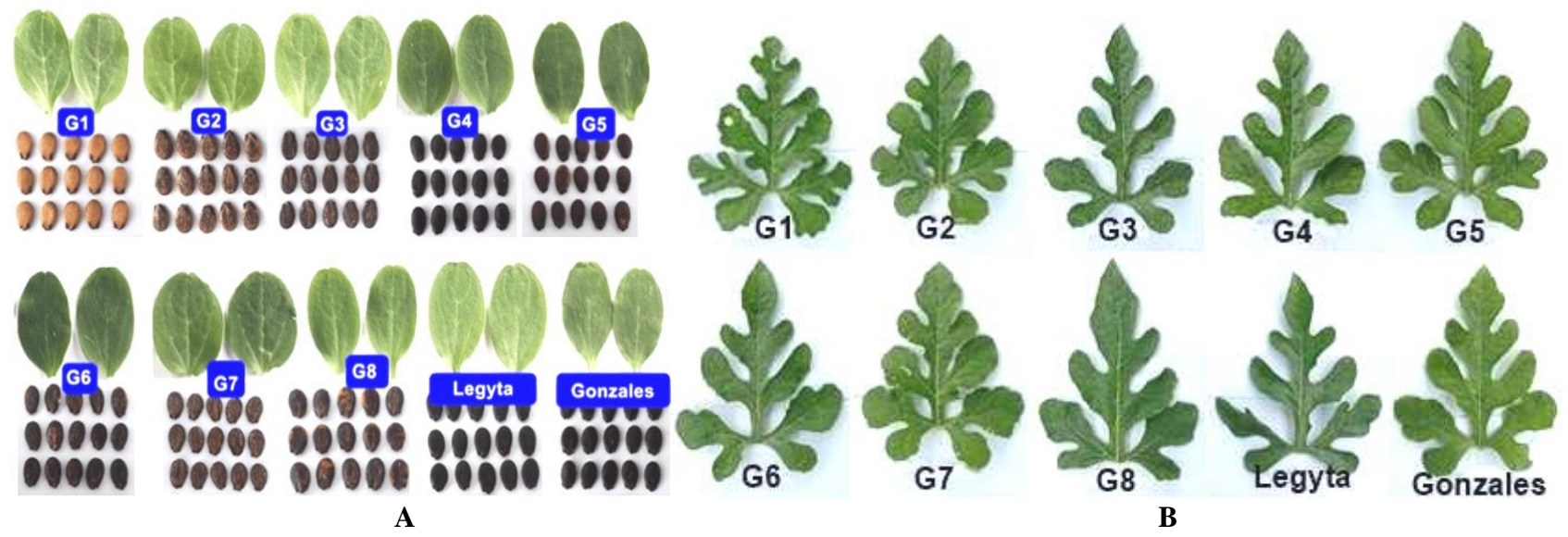

Figure 3. Morphological characters of 10 watermelon genotypes. A. Cotyledons and seeds. B. Leaf shapes

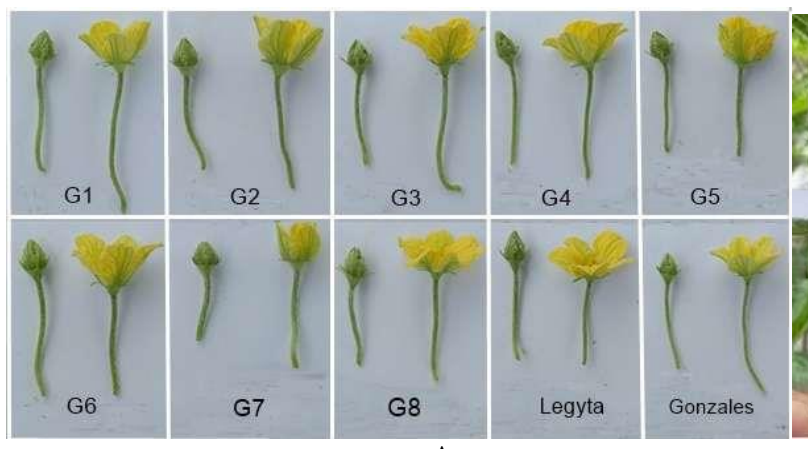

A

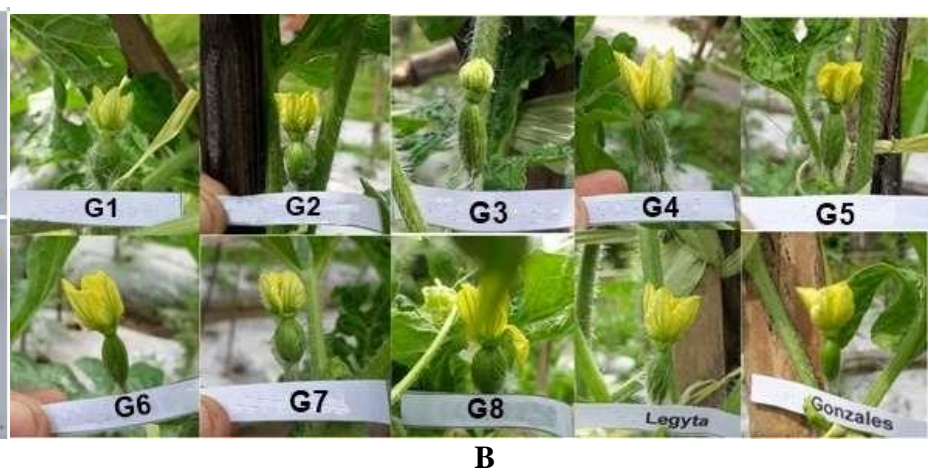

B

Figure 4. Flower morphological characters of 10 watermelon genotypes. A. Male flower. B. Female flower 


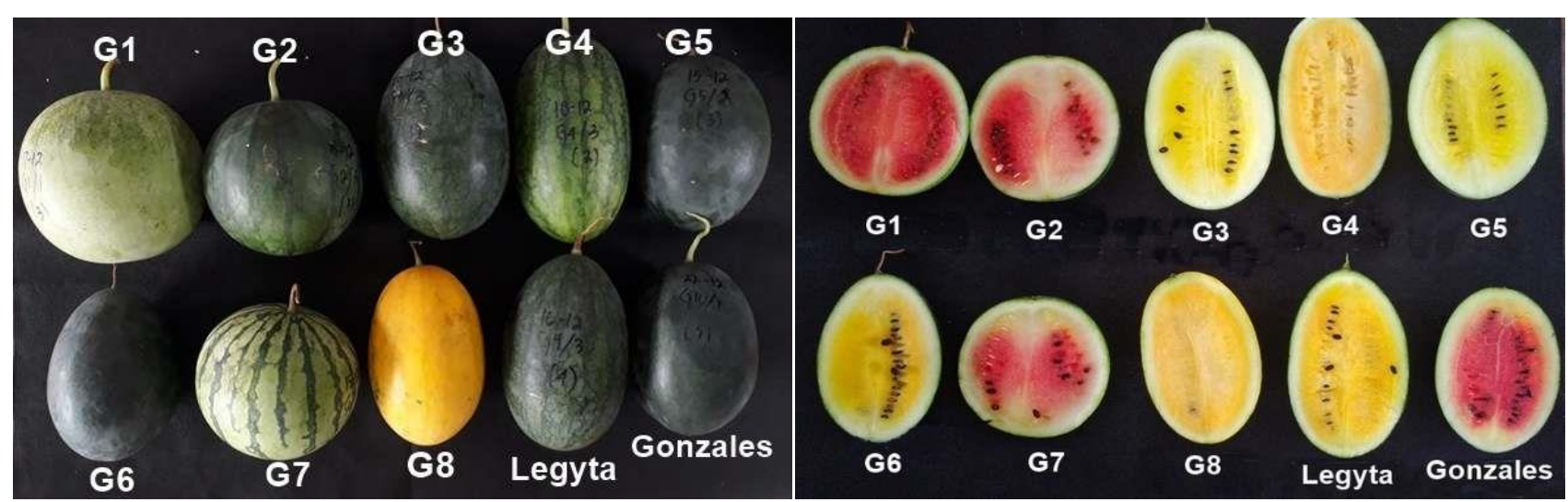

Figure 5. Fruit morphological appearance of ten watermelon genotypes

\section{Yield component and yield variables}

The Anova dan post hoc DMRT showed that flowering date, harvesting date, fruit length, fruit diameter, epidermal thickness, fruit total soluble solids, number of seeds, and fruit weight varied significantly among genotypes (Table 3; Table 4). All genotypes tested had an average harvesting date of fewer than 80 days, so all genotypes had a short harvest life. The G1 variety had the highest mean fruit weight $(3.20 \mathrm{~kg})$ while Gonzales had the lowest $(2.18 \mathrm{~kg})$. The average fruit weight of G1, G2, G6, and G7 was higher than the two check varieties (Legyta and Gonzales).

G1 had the highest average epidermal thickness of 1.23 $\mathrm{cm}$, and the lowest average epidermal thickness was G2 and G8 $(0.63 \mathrm{~cm})$. G1 had the average ideal epidermal thickness mostly preferred by farmers and had the highest average value as compared to the two check varieties. All tested genotypes had a fruit total soluble solids value of more than $8{ }^{0}$ Brix except G7.

The watermelon variety assembly program aims to create superior varieties with early maturity, high production, thick skin, and high total soluble solids in the fruit. Superior watermelon varieties are expected to have a harvest age of fewer than 80 days (Sunyoto et al. 2006), fruit weights ranging from 4-5 kg, skin thickness of 1.1-1.4 $\mathrm{cm}$ (Makful et al. 2019), and fruit total soluble solids of more than or equal to $8{ }^{0}$ Brix (United Nation Economic Commission for Europe 2017). High production is described in the character of fruit weight. Fruit length and fruit diameter are supporting characters for fruit weight characters, where there is a positive correlation between the two characters with fruit weight (Mulyani and Waluyo, 2019; Bhagyalekshmi et al. 2020).

\section{Genetic parameter analysis}

The phenotypic diversity coefficient (PDC) was greater than the genotypic diversity coefficient (PDC) in all observed quantitative characters (Table 5). PDC values greater than GDC indicate that selection can be made based on the appearance of these characters (Rabou and El-Sayed 2021). Furthermore, Ene et al. (2016) suggested that PDC, which is greater than GDC, indicates that environmental factors rather than genetic factors much more influence the character. The PDC value, which is almost the same as
GDC, shows that the environment has very little influence on the appearance of the character. Characters with almost the same PDC and GDC values were fruit length, fruit diameter, epidermal thickness, fruit total soluble solids, and number of seeds per fruit.

Heritability values in the broad sense of the watermelon genotypes tested for the evaluated characters ranged from 0.33 to 0.99 . Based on heritability criteria, the watermelon genotypes tested had moderate to high values. Characters that have high heritability values were fruit length, fruit diameter, epidermal thickness, fruit total soluble solids, and number of seeds. Characters with moderate heritability values were flowering date, harvesting date, and fruit weight. Characters with high heritability values imply that genetic influences are greater than environmental in determining character variance between genotypes (Ayaineh et al. 2012; Adjoumani et al. 2016; Anburani et al. 2019; Badami et al. 2020). Selection of these characters has a high chance of genetic advance because genetic factors strongly control the observed characters so that they will be passed on to their offsprings (Ullah et al. 2012) and selection of characters that have high heritability values can be done in the early generations (Hakim and Suyamto 2017).

\section{Correlation between quantitative characters}

Fruit weight (yield is the main component of an important melon plant because it has economic value. Breeding programs often use an indirect selection approach to improve yield characters by selecting characters that correlate with yield. The correlation between characters will facilitate selection because a decrease or increase will follow changes in the value of a character in the character (Said and Fatiha 2015). Selection will be more effective if there is a correlation between the characters to be selected (Nisha et al. 2018). The close relationship between the characters studied was estimated by using the correlation coefficient.

Positively correlated characters indicate that an increase in the value of a character will be followed by an increase in the value of other characters, while negatively correlated characters indicate that a decrease will follow an increase in the value of another character in the value of other 
characters. Fruit weight was significantly positively correlated with fruit diameter, epidermal thickness, and number of seeds (Table 6). Fruit total soluble solids were not significantly correlated with all the observed characters. Epidermal thickness was significantly positively correlated with fruit diameter. Harvesting date had a highly significant positive correlation with flowering date. The use of genotypes with large fruit diameter, thick skin, and a large number of seeds is a breeding approach for increasing fruit weight. The breeding strategy is to increase the thickness of the epidermis by using a genotype with a large fruit diameter while getting an early maturity by using a genotype with a short flowering date.

\section{Selected genotypes for plant breeding program}

The watermelon varieties to be assembled must have the characteristics of early maturity, high production, thick epidermis, and high fruit total soluble solids. Based on the research results, all the tested genotypes had a short harvesting date ( $<80$ days), so that the eight tested genotypes could be used to assemble early maturity watermelon varieties. G1, G2, G6, and G7 had higher average fruit weights than the two check varieties (Legyta and Gonzales), so they could be used to assemble watermelon varieties with high production characteristics. G1 had a thick fruit epidermal character as compared to nine tested genotypes (including comparison varieties). Furthermore, all tested watermelon genotypes had high fruit total soluble solids values ( $>8{ }^{0}$ Brix $)$ except $\mathrm{G} 7$.

Determination of genotypes that will be used as parents in the assembly of watermelon varieties in this research was based on the dendrogram results of morphological characters, assessment of quantitative characters, analysis of genetic parameters, and correlations between correlations quantitative characters. The genotypes that can assemble watermelon varieties with red flesh are G1 and G2 because they have early maturity, high fruit weight, and high fruit total soluble solids. In addition, G1 has thick fruit epidermis. The genotype that can be used to assemble watermelon varieties with yellow and/or orange flesh is G6 because it has early maturity, high fruit weight, high fruit total solids, and tends to be high in skin thickness.

The variety assembly method used to assemble the watermelon varieties produced in this research was by selection and hybridization. In watermelons with red flesh color, the selection of certain characters in the G1 and G2 lines will be very effective because it will increase these characters. The effectiveness of the selection was caused by the heritability values for the characters of harvest age, fruit weight, epidermal thickness, and total soluble solids of fruit, which had moderate to high values, so that selection on these characters had a high chance of genetic advancement.

Table 3. Characteristics of flowering date, harvesting date, fruit length, and fruit diameter of ten watermelon genotypes

\begin{tabular}{lcccc}
\hline Genotype & $\begin{array}{c}\text { Flowering } \\
\text { date } \\
\text { (days) }\end{array}$ & $\begin{array}{c}\text { Harvesting } \\
\text { date (days) }\end{array}$ & $\begin{array}{c}\text { Fruit } \\
\text { length } \\
\text { (cm) }\end{array}$ & $\begin{array}{c}\text { Fruit } \\
\text { diameter } \\
\text { (cm) }\end{array}$ \\
\hline G1 & $23.00 \mathrm{ab}$ & $65.00 \mathrm{ab}$ & $20.23 \mathrm{e}$ & $62.03 \mathrm{a}$ \\
$\mathrm{G} 2$ & $22.00 \mathrm{~b}$ & $64.00 \mathrm{~b}$ & $18.27 \mathrm{f}$ & $56.47 \mathrm{~b}$ \\
$\mathrm{G} 3$ & $23.00 \mathrm{ab}$ & $65.00 \mathrm{ab}$ & $30.30 \mathrm{~b}$ & $45.33 \mathrm{e}$ \\
$\mathrm{G} 4$ & $24.00 \mathrm{a}$ & $66.00 \mathrm{a}$ & $32.70 \mathrm{a}$ & $42.00 \mathrm{f}$ \\
$\mathrm{G} 5$ & $23.00 \mathrm{ab}$ & $65.00 \mathrm{ab}$ & $28.33 \mathrm{c}$ & $48.47 \mathrm{~d}$ \\
G6 & $24.00 \mathrm{a}$ & $66.00 \mathrm{a}$ & $26.27 \mathrm{~d}$ & $47.17 \mathrm{~d}$ \\
G7 & $21.00 \mathrm{~b}$ & $63.00 \mathrm{~b}$ & $18.87 \mathrm{ef}$ & $56.73 \mathrm{~b}$ \\
G8 & $23.00 \mathrm{ab}$ & $65.00 \mathrm{ab}$ & $30.17 \mathrm{~b}$ & $41.03 \mathrm{~g}$ \\
Legyta & $23.00 \mathrm{ab}$ & $65.00 \mathrm{ab}$ & $32.37 \mathrm{a}$ & $49.00 \mathrm{c}$ \\
Gonzales & $25.00 \mathrm{a}$ & $67.00 \mathrm{a}$ & $24.97 \mathrm{~d}$ & $40.10 \mathrm{~g}$ \\
\hline
\end{tabular}

Note: The numbers followed by the same letter in the same column are not significantly different according to the 5\% DMRT test

Table 4. Characteristics of epidermal thickness, fruit total soluble solids, number of seeds, and fruit weight of ten watermelon genotypes

\begin{tabular}{lcccc}
\hline Genotype & $\begin{array}{c}\text { Epidermal } \\
\text { thickness } \\
\text { (cm) }\end{array}$ & $\begin{array}{c}\text { Fruit total } \\
\text { soluble solids } \\
\text { ('Brix) }\end{array}$ & $\begin{array}{c}\text { Number of } \\
\text { seeds per } \\
\text { fruit }\end{array}$ & $\begin{array}{c}\text { Fruit } \\
\text { weight } \\
\text { (kg ) }\end{array}$ \\
\hline G1 & $1.23 \mathrm{a}$ & $9.00 \mathrm{~d}$ & $254.44 \mathrm{a}$ & $3.20 \mathrm{a}$ \\
$\mathrm{G} 2$ & $0.63 \mathrm{c}$ & $9.33 \mathrm{c}$ & $178.11 \mathrm{~b}$ & $2.69 \mathrm{ab}$ \\
$\mathrm{G} 3$ & $0.93 \mathrm{~b}$ & $10.44 \mathrm{a}$ & $98.56 \mathrm{bc}$ & $2.41 \mathrm{bc}$ \\
$\mathrm{G} 4$ & $0.67 \mathrm{c}$ & $8.76 \mathrm{e}$ & $118.33 \mathrm{bc}$ & $2.41 \mathrm{bc}$ \\
G5 & $0.97 \mathrm{~b}$ & $10.56 \mathrm{a}$ & $59.44 \mathrm{~d}$ & $2.46 \mathrm{bc}$ \\
G6 & $0.93 \mathrm{~b}$ & $10.00 \mathrm{~b}$ & $121.56 \mathrm{bc}$ & $2.60 \mathrm{bc}$ \\
G7 & $0.70 \mathrm{c}$ & $7.11 \mathrm{f}$ & $164.67 \mathrm{~b}$ & $2.58 \mathrm{bc}$ \\
G8 & $0.63 \mathrm{c}$ & $10.44 \mathrm{a}$ & $97.44 \mathrm{bc}$ & $2.40 \mathrm{bc}$ \\
Legyta & $0.93 \mathrm{~b}$ & $10.33 \mathrm{a}$ & $93.11 \mathrm{bc}$ & $2.48 \mathrm{bc}$ \\
Gonzales & $0.90 \mathrm{~b}$ & $9.89 \mathrm{~b}$ & $70.78 \mathrm{bc}$ & $2.18 \mathrm{c}$ \\
\hline
\end{tabular}

Note: The numbers followed by the same letter in the same column are not significantly different according to the 5\% DMRT test

Table 5. Values of environmental variance, genetic variance, phenotypic variance, heritability, GDC, and PDC of ten watermelon genotypes

\begin{tabular}{|c|c|c|c|c|c|c|}
\hline Character & $\sigma_{\mathrm{e}}^{2}$ & $\sigma_{g}^{2}$ & $\sigma_{p}^{2}$ & GDC & PDC & $\mathbf{h}^{2}{ }_{b s}$ \\
\hline Flowering date & 1.01 & 0.67 & 1.68 & 3.54 & 5.61 & 0.40 \\
\hline Harvesting date & 1.01 & 0.67 & 1.68 & 9.53 & 15.10 & 0.40 \\
\hline Fruit length & 0.74 & 29.88 & 30.62 & 20.83 & 21.08 & 0.98 \\
\hline Fruit diameter & 0.54 & 54.70 & 55.24 & 15.14 & 15.22 & 0.99 \\
\hline Epidermal thickness & 0.01 & 0.04 & 0.05 & 22.15 & 25.06 & 0.78 \\
\hline Fruit total soluble solids & 0.02 & 1.17 & 1.19 & 1.96 & 1.98 & 0.98 \\
\hline Fruit weight & 0.09 & 0.04 & 0.13 & 12.98 & 23.40 & 0.33 \\
\hline Number of seeds & 1176.44 & 3042.89 & 4219.33 & 41.48 & 48.84 & 0.72 \\
\hline
\end{tabular}

Note: $\sigma_{\mathrm{e}}^{2}$ : environmental variance, $\sigma^{2} \mathrm{~g}$ : genetic variance, $\sigma^{2} \mathrm{p}$ : phenotypic variance, GDC: genotypic diversity coefficient, PDC: phenotypic diversity coefficient, $h^{2}$ bs: heritability in the broad sense. Heritability criteria: high $\left(h^{2}{ }_{b s} \geq 0,5\right)$, moderate $\left(0,2<h^{2}{ }_{b s}<0,5\right)$, low $\left(h^{2}{ }^{2} \leq 0,2\right)$ 
Table 6. The linear correlation coefficient between characters in the watermelon genotypes tested

\begin{tabular}{lccccccc}
\hline & FD & HD & FL & FD & ST & FTSS & NS \\
\hline FD & 1.00 & & & & & & \\
HD & $1.00^{* *}$ & 1.00 & & & & & \\
FL & 0.48 & 0.48 & 1.00 & & & & \\
FD & $-0.66^{*}$ & $-0.66^{*}$ & $-0.73^{*}$ & 1.00 & & & \\
ST & -0.03 & -0.03 & 0.37 & $0.64^{*}$ & 1.00 & & 1.00 \\
FTSS & 0.31 & 0.31 & 0.51 & -0.31 & -0.07 & 1.00 & $0.77^{*}$ \\
NS & -0.43 & -0.43 & $-0.68^{*}$ & $0.85^{*}$ & $0.77^{*}$ & -0.42 & 1.00 \\
FW & -0.03 & -0.03 & -0.37 & $0.64^{*}$ & $1.00^{* *}$ & -0.07 & \\
\hline
\end{tabular}

Note: FA: flowering date, HA: harvesting date, FL: fruit length, FD: fruit diameter, ST: skin thickness, FTSS: fruit total soluble solids, NS: number of seeds, FW: fruit weight. ***significant at $5 \%$ and $1 \%$ level of probability, respectively

In addition, the assembly of watermelon varieties using the hybridization method between $\mathrm{G} 1$ and $\mathrm{G} 2$ can be carried out. G1 and G2 have a distant relationship (28.4\%) even though the two genotypes are in the same group. A cross between the two genotypes will produce a wide variation in offspring and no depression inbreeding occurs. $\mathrm{G} 1$ and $\mathrm{G} 2$ are lines that can be used as parents to assemble superior watermelon varieties with a red flesh color, while G6 are lines that can be used as parents to assemble superior watermelon varieties with an orange flesh color.

\section{ACKNOWLEDGEMENTS}

This work was a part of a cooperative between the University of Trunojoyo Madura, Indonesia and Gadjah Mada University, Yogyakarta, Indonesia. This work was also supported by a grant from the University of Trunojoyo Madura through the University's Independent Research Scheme 2019.

\section{REFERENCES}

Adjoumani K, Bony SB, Koffi GK, Kouonon LC, Brou FK, Sie R. 2016. Genetic evaluation of seed traits from intraspecific crossing of genetically distinct watermelon varieties. Afr Crop Sci J 24: 143-154. DOI: $10.4314 /$ acsj.v24i2.3.

Allard RW. 1960. Principle of Plant Breeding. John Wiley and Sons Inc., New York.

Amzeri A, Daryono BS, Syafii M. 2020. Genotype by environment and stability analyses of dryland maize hybrids. SABRAO J Breed Genet 52 (4): 355-368. DOI: 10.21107/amzeri.2020.2.

Anburani A, Kannan P, Muthumanickam K. 2019. Genetic variability, heritability and genetic advance for yield and yield components in watermelon (Citrullus lanatus Thunb.). World News Nat Sci 25: 22 30 .

Ayaineh T, Habtamu Z, Amsalu A. 2012. Genetic variability, heritability and advance in tef (Eragrostis tef (Zucc.) Troter) lines at Sinana and Adaba. Intl J Plant Breeding 6(1): 40-46. DOI: 10.3923/ijpbg.2012.40.46.

Badami K, Daryono BS, Amzeri A, Khoiri S. 2020. Combining ability and heterotic studies on hybrid melon (Cucumis melo L.) populations for fruit yield and quality traits. SABRAO J Breed Genet 52 (4): 402417. DOI: 10.21107/amzeri.2020.3.

Basyuni M, Jayusman. 2019. Plant species diversity and cluster analysis in difference logged-over peat swamp forests in Riau, Indonesia. IOP Conf. Series: Earth Environ Sci 284: 012022. DOI: 10.1088/1755$1315 / 284 / 1 / 012022$.
Bhagyalekshmi TR, Gasti VD, Evor S, Gopali JB, Mastiholi AB, Kamble CS. 2020. Studies on correlation and path-coefficient analysis for yield and its contributing characters in watermelon (Citrullus lanatus (Thunb.) Mansf.). J Pharmacogn Phytochem 9 (3): 1909-1912.

BPS-Statistics Indonesia. 2015. Harvest Area, Production, and Productivity of Watermelon in 2013. BPS, Jakarta. [Indonesian]

Casanas F, Simo J, Casais J, Prohens J. 2017. Toward an evolved concept of landraces. Front Plant Sci 8: 145. DOI: 10.3389/fpls.2017.00145.

Choudhary BR, Pandey S, Singh PK. 2012. Morphological diversity analysis among watermelon (Citrullus lanatus (Thunb) Mansf.) genotypes. Progressive Hortic 44 (2): 321-326.

FAO. 2021. Food and Agricultural Organization (FAO), United Nations.

Gbotto AA, Koffi KK, Bi NDF, Bi STD, Tro HH, Baudoin JP, Bi IAZ. 2016. Morphological diversity in oleaginous watermelon (Citrullus mucosospermus) from the Nangui Abrogoua University germplasm collection. Afr J Biotechnol 15 (21): 917-929. DOI: 10.5897/AJB2015.14701.

Jasmine MQFC, Ginting J, Siagian B. 2014. Response in growth and yield of watermelon to paclobutrazol concentration and dosage of NPK fertilizer. Jurnal Online Agroekoteknologi 2 (3): 967-974. DOI: 10.32734/jaet.v2i3.7442. [Indonesian]

Gichimu BM, Owour BO, Mwai GN, Dida MM. 2009. Morphological characterization of some wild and cultivated watermelon (Citrullus sp.) accessions in Kenya. ARPN J Agric Biol Sci 4 (2): 10-18.

Guo S, Zhang J, Sun H, Salse J, Lucas WJ, Zhang H, Zheng Y, Mao L, Ren Y, Wang Z, Min J, et al. 2013. The draft genome of watermelon (Citrullus lanatus) and resequencing of 20 diverse accessions. Nat Genet 45: 51-58. DOI: 10.1038/ng.2470.

Hakim L, Suyamto. 2017. Gene Action and heritability estimates of quantitative characters among lines derived from varietal crosses of soybean. Indonesian J Agric Sci 18: 25-32. DOI: 10.21082/ijas.v.18.n1.2017.p.25-32.

Kartahadimaja J, Utomo SD, Yuliadi E, Salam AK, Warsono, Wahyudi. 2021. Agronomic characters, genetic and phenotypic diversity coefficients, and heritability of 12 genotypes of rice. Biodiversitas 22 (3): 1091-1097. DOI: 10.13057/biodiv/d220302.

Khairullah I, Saleh M, Mawardi. 2021. The characteristics of local rice varieties of tidal swampland in South Kalimantan. IOP Conf. Series: Earth Environ Sci 762: 012009. DOI: 10.1088/17551315/762/1/012009.

Kuswantoro H. 2017. Genetic variability and heritability of acid-adaptive soybean promising Lines. Biodiversitas 18: 378-382. DOI: 10.13057/biodiv/d180149.

Levi A, Jarret R, Kousik S, Wechter WP, Nimmakayala P, Reddy U. 2017. Genetic resources of watermelon. Genet Genom Cucurbitaceae 20: 87-110. DOI: 10.1007/7397_2016_34.

Makful, Kuswandi, Sahlan, Andini M. 2019. Evaluation of the performance of some watermelon hybrid collection of Indonesian tropical fruit research. Jurnal Budidaya Pertanian 15 (2): 101-105. DOI: 10.30598/jbdp.2019.15.2.101. [Indonesian]

Munisse P, Andersen SB, Jensen BD, Christiansen JL. 2011. Diversity of landraces, agricultural practices and traditional uses of watermelon (Citrullus lanatus) in Mozambique. Afr J Plant Sci 5 (2): 75-86.

Nisha SK, Sreelathakumary I, Celine VA. 2018. Variability, interrelationship and path coefficient studies in watermelon. Indian J Hortic 75 (4): 619-624. DOI: 10.5958/0974-0112.2018.00103.2. 
Ene CO, Ogbonna PE, Agbo CU, Chucwudi UP. 2016. Studies of phenotypic and genotypic variation in sixteen cucumber genotypes. Chilean J Agric Res 76 (3): 307-313. DOI: 10.4067/S0718 58392016000300007.

Pessoa AM, Dos S, Rego ER, Barosso PA, Rego MM. 2015. Genetic diversity and importance of morpho-agronomic traits in a segregating F2 population of ornamental pepper. Acta Hortic 107: 195-200. DOI: 10.17660/ActaHortic.2015.1087.23.

Rabou AMA, El-Sayd EM. 2021. Genetic variability, heritability and correlation in watermelon. Egypt J Appl Sci 36 (3): 43-58

Saediman H, Alwi LA, Rianse IS, Taridala SAA, Salahudin S, Indarsyih Y, Astuti RW. 2020. Comparative profitability of melon and watermelon production in South Konawe District of Southeast Sulawesi. WSEAS Transactions Bus Econ 17: 933-939. DOI: 10.37394/23207.2020.17.91.

Said EM, Fatiha H. 2015. Genotypic variation in fruit characters in some genotypes of watermelon cultivated in Marocco. Intl J Agronom Agric Res 6 (4): 130-137.

Samadia DK, Haldhar SM. 2020. Mateera, watermelon (Citrullus lanatus) germplasm utilization for improving fruit quality and marketable harvest under hot arid climate of India: Approaches and out-put. J Agric Ecol 10: 1-21. DOI: 10.53911/JAE.2020.10201.

Singh RK, Chaudary BD. 1979. Biometrical Methods in Quantitative Genetic Analysis. Kalyani Publisher, New Delhi.

Suhartono, Soegianto A, Amzeri A. 2020. Mapping of land potentially for maize plant in Madura Island-Indonesia using remote sensing data and geographic information systems (GIS). Eco Environ Cons 26: 145-155
Sunyoto D, Sudarso T, Budiyanti. 2006. Petunjuk Teknis Budidaya Semangka. Balai Penelitian Tanaman Buah Tropika. Solok, Sumatra Barat, Indonesia. [Indonesian]

Uslan, Asmiati, Lestari N. 2020. Diversity and clustering analysis of Sterculia quadrifida R.Br from Kupang, East Nusa Tenggara, Indonesia based on morphological and anatomical characters. IOP Conf Series: Earth Environ Sci 456: 012069. DOI: 10.1088/17551315/456/1/012069.

Ullah MZ, Hassan MJ, Chowdhury AZMKA, Saki AI, Rahman AHMA. 2012. Genetic variability and correlation in exotic cucumber (Cucumis sativus L.) varieties. Bangladesh J Pl Breed Genet 25: 1723.

Vinhas AS, Sousa C, Matos C, Moutinho C, Vinha AF. 2021. Valorization of watermelon fruit (Citrullus lanatus) by-products: Phytochemical and biofunctional properties with emphasis on recent trends and advances. World J Adv Healthcare Res 5: 302-309.

Walpole RE. 1982. Introduction of statistics (3rd Edition). Macmillan Publishing Company, Inc., New York.

Walters SA, Abdelazis M, Bouharroud R. 2021. Local melon and watermelon crop populations to moderate yield responses to climate change in North Africa. Climate 9 (8): 1-13. DOI: $10.3390 /$ cli9080129.

Wehner TC, Naegele RP, Veazie PP. 2017. Heritability and genetic variance components associated with citrulline, arginine, and lycopene Content in diverse watermelon cultigens. Hortic Sci 52 (7): 936-940. DOI: 10.21273/HORTSCI11255-16. 